\title{
Discussions on Class Management of Class Advisers in Higher Vocational Colleges
}

\author{
Hongxia Huang, Baohua Cui, Chao Xu and Xiaoming Zhang \\ Jibei Electric Power Company Limited Skills Training Center \\ Baoding, China \\ e-mail: hhx_1982@163.com
}

\begin{abstract}
The class management of class advisers in higher vocational colleges is an important job in higher vocational education, and it plays irreplaceable role in the cultivation of students' professional quality, occupation spirit, personality, and social responsibility. This paper firstly summarizes the characteristics of the higher vocational college students: poor study ability, poor self management and being lack of upward mobility. Then based on the characteristics of the students, management methods for class advisers are proposed: understanding students, establishing a class management team, establishing reasonable class systems, establishing good class atmosphere, and conducting employment education. Finally, the hierarchy of the management methods is summarized. It gives scientific and reasonable management methods for class advisers in vocational colleges. This paper can provide references for class management and student education in higher vocational colleges.
\end{abstract}

Keywords-class management; class adviser; higher vocational college, class committee member

\section{INTRODUCTION}

With the deepening of economic reform, vocational education, especially hither vocational education rapidly develops in China [1]. Higher vocational education is an important part of higher education. The guideline of higher vocational education is "service, employment, and the production - study - research combination". It aims to train practical and technical persons of theoretical basis and practical ability, and takes an important task of transporting qualified builders to the society. The management of higher vocational students is an important job in higher vocational education, and it plays irreplaceable role in the cultivation of students' professional quality, occupation spirit, personality, and social responsibility. Class is a basic unit of school education and management activities. Class advisers are the direct educators, guiders and organizers of the students in higher vocational school [2]. They directly influence the formation of students' ideological and moral concepts, scientific beliefs and right social values, thus they play a decisive role in the micro social system of higher vocational education. In the popular education times, the class adviser, as the main manager of the class, is given a deep meaning [3].

\section{CHARACTERISTICS OF THE HIGHER VOCATIONAL COLLEGE STUDENTS}

Because of the particularity of the higher vocational education, the students of higher vocational college inevitably have different characteristics with those of other universities.

\section{A. Lack of self-confidence and upward mobility}

On the one hand, as the higher vocational college is the last batch of admission, the students have to enter higher vocational colleges because of low scores. The gap between reality and ideals causes psychological loss. They doubt themselves, and then inferiority rises. On the other hand, the whole society in China is lack of understanding of the vocational education, and the employers have some misunderstanding against the higher vocational education. People only consider academic qualifications, and think that the higher vocational students can only be engaged in relatively simple and low salary jobs. To the higher vocational college students, these misunderstanding cause them be under great pressure of social identity. Thus they are lack of confidence, self-abased, and feel confused about the future [4].

\section{B. Lack of learning autonomy}

Failed to develop good study habits and attitudes in the high school stage, the higher vocational college students rely too much upon the teacher's explanation [4], thus they are deficient of independent thinking and lack of initiative and exploratory. Many students study in passive states. They do not study in spare time. They even do not preview, study, and review. Some students cannot understand the study contents in the learning process, gradually lose interest in learning, and begin to talk or sleep in classes, or even skip lessons, therefore their achievement further decline and a vicious circle is formed.

\section{Poor self management}

At present China, most students come from singlechild family and they are much spoiled by their parents. Their parents tend to ignore how to educate the children be self-care, self-reliance, self-control and upright. Therefore, the higher vocational college students are lack of independence and self-discipline. They even do not follow discipline of the school.

The characteristics of poor study ability, poor self management and being lack of upward mobility determine the management method of the class advisers. The class advisers should firstly understand and analyze the current 
ideological situation of the higher vocational college students and then choose corresponding management methods [3].

\section{MANAGEMENT METHODS OF CLASS ADVISERS IN HIGHER VOCATIONAL COLLEGE}

\section{A. Comprehensive understanding students}

In order to make the class management on the right track since the enrollment of the students, the class advisers should communicate with every student and master class situation. Firstly, since the students enter the higher vocational college, through chatting with each student face to face, the class advisers can obtain the details about the family situation, character and score of each student, thus a special communicate way between teachers and students can be established [5]. For family situation, considering students' introverted personality and individual privacy, the class advisers can ask students to write down their family situation, especially the economic conditions and the family members. To those students who were difficult in economic conditions, the class advisers should encourage them to keep a positive attitude and be confident, introduce the perfect scholarship system and incite them to complete their study under the perfect scholarship system. Secondly, the class advisers should make full use of the enrollment file information. From the files, class advisers can comprehensively understand the performance of the students in their middle schools [3]. Thirdly, in spare time, the class advisers should frequently go to the classroom and dormitory. Through chatting with students, class advisers can better understand the daily life and learning conditions of the students, they can also timely understand the ideological trends and difficulties of students. Thus, class advisers can help students gradually adapt to learning life, discipline and daily life in higher vocational college and guide them to adjust their mentality and handle problems they encountered.

When communicating with students, class advisers should take different approaches for students with different personalities. For introverted students, encouragement can be used, and they are encouraged to communicate more with classmates, and participate more in collective activities. For outgoing students, guidance can be used, therefore, they are requested to participate in community activities and improve their individual qualities.

\section{B. Establish a class management team}

Successful management of a class depends on an efficient student management team. The establishment of a class committee is the basis of the class management. The class committee is the bridge between the teacher and the student, and it is an important assistant of class advisers. In order to make full use of the management function of the class committee, the members should be seriously considered. The class committee member requires following characteristics: having a certain appeal, having a strong sense of service and having a strong sense of class honor [6]. After the students enter the school, for they are not very familiar with each other, election work for the class committee member is inappropriate at this moment. The class advisers can appoint a student to be responsible for class affairs for the occasion. When the students are familiar with each other, election work can be carried on, thus the class committee members are determined. Secondly, the class advisers should constantly attend the class committee member meeting. On the one hand, the problems that exist in class can be widely discussed and solutions can be found. On the other hand, comments and suggestions for class management can be given, and the class management methods can be improved. Thirdly, the class advisers should frequently help the class committee members to enhance their management level. Incentive measures can be adopted. Thus, their ability of management, organize and handle affairs can be enhanced.

\section{Establish good class atmosphere}

Class atmosphere mainly refers to the students' learning atmosphere, it is the external reflection of the students' learning attitude, learning objective, learning methods and learning ability. It also expresses the behavior, psychology and comprehensive quality of the class members [7, 8]. Positive class style, strong class cohesion, and harmonious teacher-student relationship, are the signs of the formation of class atmosphere [8].

Firstly, students should be led to form correct learning attitudes and establish clear learning objectives. The class advisers should strengthen the students' cognition to higher vocational education, guide them to correct self positioning from the social needs and the future development, and help them to develop a clear leaning goal and make a career planning. With the right learning objectives, students have the motivation to learn [6]. Secondly, students should be led to develop right leaning methods and adapt to higher vocational college life. After the students enter the school, a community experience exchange meeting and a learning experience exchange meeting can be arranged. The learning experience exchange meeting aims to lead the students to adapt to the higher vocational college life as soon as possible, and help them to develop suitable learning method and integrate into the rhythm of higher vocational college life. The community experience exchange meeting aims to help the students to enrich their higher vocational college life, and to treat the relationship between community and learning scientifically and rationally. The exchange meetings can solve the confusion of the students for study and life. They can also stimulate the study passion and target of students. Thirdly, supervision and inspection should be strengthened. Class attendance checking should be implemented. Attention is fixed on the phenomenon of being late and absent. Through communicate with the students who are late and absent, class advisers can stop the spread of adverse phenomenon in time, and create an orderly atmosphere in the class. Finally, a good learning environment should be actively created. Through classroom duty, posters, book corner and other activities for students, a clean, tidy, and positive learning environment can be formed [9]. In addition, various forms of class activities, such as entertainment, sports, extracurricular reading, knowledge contests and public welfare activities, can cultivate students' sentiment, and enhance their spirits of collaboration and team work.

\section{Establish reasonable class systems}

The establishment of class systems directly influences the normal development of class affairs. Following class 
systems can be established. Firstly, a poor students' recognition system can be established. Poverty degree classification directly influences the harmony and solidarity of students. A class classification group for poverty degree can be established. The group members include the class committee member and ordinary students. The group should cover every dormitory. Some indexes, such as family income, family student number and family debt number are selected, and the values for these indexes are listed. Based on the indexes values, the poverty degree can be determined by the classification group. This classification method depends on objective data and it can avoid subjectivity in poverty degree classification. Secondly, an English $\mathrm{AB}$ level simulation test system can be established. All the students are requested to take part in the simulation test every week. The simulation test can efficiently monitor students' English learning situation, enhance their English level and improve their passing rate in English AB level test. Thirdly, a class problem feedback system can be established. In order to discover the students' problems in time, class advisers can communicate with the students in spare time through the Internet. In addition, class advisers can visit the dormitory at irregular intervals to check dormitory situation and communicate with students, thus class problems can be found. For the problems of individual student, such as no study in spare time, class advisers should quickly correct them. For the problems of most students, class meeting should be held to tell the existence of the problems and require students to solve them. For the students who are poor in study basis or not active in learning, class advisers can adopt interview method. By face to face chatting, they are requested to adjust the strategy to improve learning performance at study.

\section{CONDUCT EMPLOYMENT EDUCATION}

Employment and career choice are the key stage for the students to enter society. In recent years, with the expansion of higher education, the number of college graduates is increasing rapidly, and the pressure of the students' employment is increasing[12, 13]. Under the stern employment situation, it has become important to help the higher vocational college students to reach a good professional and psychological basis. As the direct manager of students, the class adviser plays an important role in the students' career guidance, and has irreplaceable function.

Employment education should be conducted throughout the higher vocational college stage. Since the students enter the school, class advisers must shoulder the responsibilities of the students' employment and career choices. According to students' different needs in different stages, class advisers should carry out the employment education in different levels [9]. The contents of the employment education in different levels are shown in Table 1. The education contents in Grade 1 are: understanding major and occupation, improving the ability and adapting to society. Students can have a more comprehensive understanding of the major, then love the major, and enhance their learning interest, therefore lay a good foundation for future employment. To promote students' rational understanding of the major, the class advisers can invite professional personage to give lecture on major education. On the basis of major education, the class advisers can guide the students to work out their learning plan, quality development plan and career plan based on their own interest, expertise, and ability. The education contents in Grade 2 mainly focus on professional competence. Students are guided to improve their own practical ability based on their course learning and social practices. Foreign language ability and computer skills should be also improved to enrich students' own quality for employment and career choice. Students are also encouraged to obtain relevant qualification certificates, such as national computer grade certificate and English grade certificate. In addition, class advisers should encourage students to actively participate in social practice activities, such as summer employment and spare time employment. The education contents in Grade 3 mainly focus on employment guidance. Firstly, through face to face communication, the class advisers should give advice to students' employment intention based on students' own situation. Secondly, class advisers should guide students to prepare their employment materials and improve their job interview skills. Class meeting can be held to guide students to prepare employment materials. Watching job application videos and communicating with alumni can help students to better understand the basic requirements and skills of job application. Simulation recruitment can be held to let students experience the interview process in advance and overcome the psychological fears. Thirdly, class advisers should guide students to correct their attitudes for employment and properly handle anxiety, inferiority, and cowardly psychological contradictions when applying a job [10].

TABLE I. EMPLOYMENT EDUCATION IN DIFFERENT LEVELS

\begin{tabular}{|c|c|c|}
\hline Level & Main contents & $\begin{array}{l}\text { What the class advisers should } \\
\text { do }\end{array}$ \\
\hline $\begin{array}{l}\text { Grade } \\
1\end{array}$ & $\begin{array}{l}\text { Understanding major } \\
\text { and occupation }\end{array}$ & $\begin{array}{l}\text { Conducting major education; } \\
\text { Guiding students to work out their } \\
\text { learning plan, } \\
\text { Guiding students to work out } \\
\text { quality development plan; } \\
\text { Guiding students to work out } \\
\text { career plan }\end{array}$ \\
\hline $\begin{array}{l}\text { Grade } \\
2\end{array}$ & $\begin{array}{l}\text { Improving } \\
\text { professional } \\
\text { competence }\end{array}$ & $\begin{array}{l}\text { Guiding students to improve } \\
\text { practical ability; } \\
\text { Guiding students to improve } \\
\text { foreign language ability; } \\
\text { Guiding students to improve } \\
\text { computer skills; } \\
\text { Encouraging students to obtain } \\
\text { qualification certificates; } \\
\text { Encouraging students to participate } \\
\text { in social practice activities }\end{array}$ \\
\hline $\begin{array}{l}\text { Grade } \\
3\end{array}$ & Employment guidance & $\begin{array}{l}\text { Guiding the students to prepare } \\
\text { employment materials; } \\
\text { Guiding the students to improve } \\
\text { job interview skills. } \\
\text { Guiding students to correct their } \\
\text { attitudes for employment } \\
\text { Guiding students to properly } \\
\text { handle anxiety, inferiority, and } \\
\text { cowardly psychological } \\
\text { contradictions }\end{array}$ \\
\hline
\end{tabular}






Figure 1. The Hierarchy of the Management Methods

Fig .1 illustrates the hierarchy of the management methods listed above. Understanding the students is the basis of class management. Once the class adviser comprehensive understanding the detailed condition of the class, the class committee can be properly established. And reasonable class systems can be established. The class committee and the class systems are the guarantees to form a good class atmosphere. Employment education helps students to obtain strong competitiveness for applying a job. All the management methods are aiming to cultivate a outstanding graduates.

\section{CONCLUSIONS}

Higher vocational college is an important part of higher education system in China. It has pivotal significance especially in the process of cultivating technical talents. The class adviser is the leader of a class. The work of the class adviser plays an important role in the growth and development of the higher vocational college students. Improving management level is a responsibility for students.

Exploring new ideas and new methods has become a difficult task to bring the class management to a new situation. In the course of the class management, class advisers will certainly encounter all kinds of complicated problems. The characteristics of the higher vocational college students should be considered in class management and problem solution. The methods of management and education should keep pace with the times. Therefore, scientific and reasonable management methods can be obtained for higher vocational college students. Thus, outstanding graduates can be cultivated.

\section{REFERENCES}

[1] D. Zhao, "Discussion on the communication between class advisers and students education in higher vocational college," Education and Teaching Forum, 16, pp. 109-110, 2013.

[2] Y. Nie, "Discussion on how to carry out the class work for class advisers in higher vocational college," Success, 6, pp. 89-90, 2010.

[3] L. Ma, "Discussion on management art of class advisers in higher vocational college," Journal of Xinxiang Education College, Vol.22(1), pp. 28-29, 2009.

[4] S. H. Li, "The dual role of class advisers from the psychological characteristics of higher vocational college students," Examination weekly, 64, pp. 155-156, 2013.

[5] Y. P. Gao, "The perception of the class adviser work in higher vocational college," Academy, 19, pp. 47-48, 2014.

[6] W. M. Zhou, "Exploration and practice of class adviser's work in professional colleges," Journal of Hunan Metallurgical Professional Technology College, Vol. 7(2), pp.75-76, 2007.

[7] B. L. Gao, "Discussion on class management in higher vocational colleges," Examination weekly, 68, pp. 186, 2013.

[8] X. L. Zhou, "Ideas and Practice of Head teacher's Work in Higher Vocational College," Journal of Zhejiang Industry \& Trade Vocational College, Vol. 9(3), pp. 15-18, 2013

[9] W. Q. Zhu, "How to give a good class meeting as a class teacher in higher vocational colleges," Journal of Nanchang Education College (higher vocational education), vol. 26(8), pp. 80-81, 2001

[10] F. Xie, "Discussion on job application guide of class advisers in higher vocational colleges," China Electric Power Education, 11, pp. 167-169, 2009.

[11] P. H. Qiao, and L. L. Yin, Employment and entrepreneurship guidance for college students. Beijing: Machinery Industry Press, 2010.

[12] G. Q. XU, Curriculum theory of Vocational Education, 2nd ed., Shanghai: East China Normal University Press, 2015. 